\title{
AN ANALYSIS OF OUTCOME AND COMPLICATIONS OF MICROVASCULAR FREE FLAP HEAD AND NECK RECONSTRUCTION
}

\section{Dr. Nitin Tomar}

\section{Dr. Ayush Naik*}

Assistant Professor, Department of Ear, Nose and Throat , Government Cancer Hospital, M.G.M Medical College, Indore-452001.

Assistant Professor, Department of Radiation Oncology, Government Cancer Hospital, M.G.M Medical College, Indore-452001. *Corresponding Author

Dr. Ashish Malviya

Senior Resident, Department of Radiation Oncology, Government Cancer Hospital, M.G.M Medical College, Indore-452001.

Dr. Abhishek Pratap Post Graduate Resident III, Department of Radiation Oncology, Singh

ABSTRACT Background: Microvascular free flap transfers have become a preferred reconstructive technique; however, rare complica-tions may still prove devastating.

Aim: The objective of this study was to evaluate the clinical outcomes in Head and neck cancer patients undergoing different microvascular free flap reconstructions.

Materials and Methods: his study analyzed the surgical out-come and complications of 200 microvascular free flaps head and neck reconstruction. In most cases, after resection of the malignant tumor, reconstruction was undertaken . Four types of free flap were performed as follows: Anterolateral thigh (80\%), radial forearm (15\%), fibula (4\%), and jejunum (1\%). The most commonly used as recipient vessels for anastomosis were superior thyroid artery and the external jugular vein. The incidence of perioperative complications and Patient-related characteristics (age, sex, diagnosis, comorbidity, level, tumor stage, defect site, primary versus secondary reconstruction, and history of surgery, radiation therapy, or chemotherapy) were recorded prospectively.

Observations and results: Emergency surgical re-exploration was required in nine patients and the overall flap success rate was $95.3 \%$. Venous thrombosis was the most common cause for re-exploration. Other complications included wound infection (12.5\%), wound dehiscence (15\%), partial flap necrosis $(2.5 \%)$, fistula formation $(9.5 \%)$, and bleeding (1.5\%). Recipient and donor site morbidity was limited and considered acceptable.

Conclusions: Micro surgical free flap is shown to be a valuable and reliable method in head and neck surgery which can be used effectively and safely with minimal morbidity in selected patients. When performed by skilled surgeon, reconstruction can be performed with acceptable outcomes and early re-exploration should be the first choice for the management of vascular compromised flaps.

\section{KEYWORDS : head and neck cancer, micro-vascular free flap reconstructions.}

\section{INTRODUCTION}

Head and neck cancer is the sixth common cause of cancer with an estimated worldwide incidence of over 600,000 new cases annually.[1,2] Surgery for tumors of head and neck can cause significant soft tissue, bony, and skin defects which result in cosmetic as well as functional impairment like speech and swallowing deficits. Thus, the reconstruction of extensive defects after resection has always been challenging.

The development and refinement of micro-vascular surgical techniques have improved the reported overall success rates to between 94 and 99\%; however, rare complications may still prove devastating.[3-6] . Several Authors have reported numerous factors associated with development of complications of microvascular free tissue transfer and classified them into recipient site or donor site complications. $[3,4]$

The aim of this study was to assess the incidence and causes of complications in patients undergoing micro-vascular free flap reconstruction for surgical defects of the head and neck and to identify the variables that influence both medical and reconstructive complications. by analyzing a series of 200 consecutive free flap reconstructions.

\section{MATERIALS AND METHODS:}

In present retrospective analysis, a total of 200 head and neck cancer patients were analyzed who underwent consecutive free flap procedures for reconstruction of defects in the head and neck region at Government Cancer Hospital, Indore, between 2005 and 2017. All patients were clinically staged was performed according to the seventh edition of the UICC/AJCC TNM staging system. [3,5]

Following surgery, flaps were monitored every $2-3 \mathrm{~h}$ for $12 \mathrm{~h}$, every 4-6 h for $12-24 \mathrm{~h}$, every $6-8 \mathrm{~h}$ for $24-48 \mathrm{~h}$, and 3 times daily thereafter. The perioperative complications were observed and data including age, sex, diagnosis, radiotherapy, free flap type, and vessels for anastomosis were noted and analyzed retrospectively. The main outcome measures were complications occurring within 30 days of surgery. Complications were then categorized as recipient site or donor site complications.

Following surgery, flaps were monitored every $2-3 \mathrm{~h}$ for $12 \mathrm{~h}$, every $4-6 \mathrm{~h}$ for $12-24 \mathrm{~h}$, every $6-8 \mathrm{~h}$ for $24-48 \mathrm{~h}$, and 3 times daily thereafter. The perioperative complications were enumerated in Table 2. Data includ-ing age, sex, diagnosis, radiotherapy, free flap type, and vessels for anastomosis were analyzed retrospectively. The main outcome measures were complications occurring within 30 days of surgery. Complications were categorized as recipient site or donor site complications in Tables 3 and Table 4.

\section{OBSERVATIONS AND RESULTS:}

There were 135 men and 65 women in present study. The mean age of patients was 45.4 years. The patient characteristics are detailed in Table 1. The Anterolateral thigh (ALT) flap was the flap most often harvested in our patients $(n=160)$. The Rectus femoris (RF) flap was the second most used after the ALT flap 
( $n=30)$, followed by the fibula myocutaneous flap $(n=8)$ and the jejunum flap $(n=2)$.

The buccal mucosa was the site most commonly involved ( $n=$ $62)$, followed by tongue $(n=42)$, lip $(n=35)$, gum $(n=20)$, jaw bone $(n=18)$, floor of the mouth $(n=8)$, the oropharynx $(n=$ $7)$, hypopharynx $(n=5)$, sublingual gland $(n=2)$, and larynx $(n=1)$.

The most common tumor diagnosis was squamous cell carcinoma ( $n=177 ; 88.5 \%)$, followed by salivary gland carcinoma $(n=11 ; 5.5 \%)$, sarcoma $(n=5 ; 2.5 \%)$, undifferentiated carcinoma $(n=4 ; 2 \%)$, and odontogenic carcinoma $(n=2 ; 1 \%)$.

The tumor stages were as fol-lows: Stage I in 15 patients (7.5\%), Stage II in 45 patients $(22.5 \%)$, Stage III in 58 patients (29\%), and Stage IV in 82 patients (41\%).

\section{RECIPIENT SITE COMPLICATIONS}

Post-operative vascular thrombosis occurred in seven cases (six venous and one arterial), constituting $3.5 \%$ of the entire series. The rate of successful salvage of vascu-lar compromised flap by urgent surgical procedure was $100 \%$. Five flaps were salvaged by surgical re-exploration or thrombolytic therapy, resulting in a $71.4 \%$ of successful salvage rate in cases of vascular complications. The overall free flap success rate was $95.3 \%$ in this series. The most common complication of the recipient site was wound dehiscence ( $n=30 ; 15 \%)$, followed by wound infection ( $n=$ $25 ; 12.5 \%)$ and fistula formation $(n=19 ; 9.5)$. These cases were treated successfully with local wound care, debridement, and intravenous antibi-otic agent.

Table 1: Clinical data analyses of the patients who underwent free flap for reconstruction

\begin{tabular}{|l|l|l|}
\hline Variables & Number & Rate (\%) \\
\hline Gender & 135 & 67.5 \\
\hline Male & 65 & 32.5 \\
\hline Female & 91 & 45.5 \\
\hline Age (years) & 109 & 54.5 \\
\hline$<45$ & 160 & 80 \\
\hline$\geq 45$ & 30 & 15 \\
\hline Flap types & 5 \\
\hline ALT flap & 10 & 30 \\
\hline RF flap & 60 & 70 \\
\hline Fibula myocutaneous flap & 10 \\
\hline TNM classification & 140 & 7.5 \\
\hline I+II & 92.5 \\
\hline III+IV & 15 & 21 \\
\hline Local recurrence & 185 & 79 \\
\hline Yes & \multicolumn{2}{|l}{} \\
\hline No & 158 & \\
\hline Distant metastasis & \multicolumn{2}{|l|}{} \\
\hline Yes &
\end{tabular}

Table 2: Perioperative medical complications

\begin{tabular}{|l|l|}
\hline Medical complication & Number of occurrences (\%) \\
\hline Respiratory & $24(12.0)$ \\
\hline Cardiac & $19(9.5)$ \\
\hline Infectious & $23(11.5)$ \\
\hline Neurological & $3(1.5)$ \\
\hline Vascular & $4(2.0)$ \\
\hline Perioperative death & $3(1.5)$ \\
\hline
\end{tabular}

Table 3: Recipient site complications

\begin{tabular}{|l|l|}
\hline Number of cases & Incidence (\%) \\
\hline
\end{tabular}

Vascular thrombosis (six venous, one arterial) 7 (3.5)

\begin{tabular}{|l|l}
\hline Total flap loss (one radial forearm, one & 2 (1)
\end{tabular} scapula)

\begin{tabular}{|l|l|}
\hline $\begin{array}{l}\text { Partial flap loss four rectus abdominis, one } \\
\text { scapula) }\end{array}$ & $5(2.5)$ \\
\hline Wound infection & $25(12.5)$ \\
\hline Wound dehiscence & $30(15)$ \\
\hline Fistula formation & $19(9.5)$ \\
\hline Cervical hematoma & $3(1.5)$ \\
\hline
\end{tabular}

Table 4: Donor site complications

\begin{tabular}{|l|l|l|}
\hline Flap complication & $\begin{array}{l}\text { Number of } \\
\text { cases }\end{array}$ & Incidence, \% \\
\hline Rectus abdominis myocutaneous flap \\
\hline Abdominal hernia & 3 & 1.5 \\
\hline Infection & 5 & 2.5 \\
\hline Wound dehiscence & 5 & 2.5 \\
\hline Radial forearm flap & 9 \\
\hline Partial loss of skin graft Scapula & 18 & 14.5 \\
\hline Osteocutaneous flap & \\
\hline Limitation of shoulder motion & 29 \\
\hline
\end{tabular}

\section{DISCUSSION}

Surgical treatment of patients with head and neck cancer was revolutionized during the 1970s with the development and clinical application of microvascular free flaps and pedicled myocutaneous flaps for head and neck reconstruction. [1,3,4]

Micro-vascular anastomoses are much less prone to thrombosis when they have an external diameter that exceeds $1 \mathrm{~mm}$, five and all of the flaps used in this series contained nutrient blood vessels with diameters that usually exceeded 2 $\mathrm{mm}$. O'Brien et al.. in their study analyzed 250 free flaps and reported that patients undergoing jaw reconstruction compared with reconstruction of other defects in the head and neck had an increased risk of flap failure .[2]

Overall, good post-operative monitoring and early detection of compromised flap perfusion leading to early interventions can result in successful salvage rates of $70 \%$ as Brown et al. in 2003 showed in 427 free flaps. [1]

It is striking to note the high incidence of primary wound healing in the head and neck in patients who undergo free flap reconstruction in present study. In the present study , the incidence of complications were indicative low wound healing in delayed flap recipient.

While the incidence of total flap necrosis in pedicled myocutaneous flaps in present study is similar to that reported in recent studies analyzing micro-vascular flap reconstruction, the incidence of partial flap necrosis is consistently higher for regional flaps than that reported for free flaps. Partial flap necrosis frequently leads to delayed wound healing including salivary fistula formation. Shah et al. reported a $29 \%$ incidence of partial flap necrosis in a series of 211 pectoralis major myocutaneous flaps used for head and neck reconstruction, [4] while Schusterman et al. reported partial flap necrosis in $14 \%$ of pectoralis major myocutaneous flaps used for intraoral soft tissue reconstruction. [5]

Ferri et al. reported a $14 \%$ incidence of salivary fistula formation in a series of 85 pectoralis major myocu-taneous flaps used for head and neck reconstruction.[6] In a survey of otolaryngology residents graduating in 1997, 85 respondents reported exposure to 1637 pedicled flap and 870 free flap procedures.[7] This phenomenon is likely secondary to a variety of factors including persisting misconceptions regarding free flap reliability and a lack of surgeons with training in microvascular surgery in some centers.[7-11] In addition, concerns regarding the potential for the development of periop-erative medical complications after lengthy surgery may also contribute to a reluctance to consider the use of free flaps.[12-15] 
Our findings are cohrent to those reported by Singh et al., who noted a significant correlation between comorbidity level and the incidence of complications. [3] Singh et al. also noted that age older than 70 years was associated with increasing complication severity.

\section{CONCLUSIONS}

A wide range of reconstructive options are available for composite defects resulting from the treatment of head and neck cancer, the efficacy of which depends on the specific anatomy of the defect, planned outcome, the patient's tolerance for donor site morbidity, and the surgeon's training and experience.

In the present study, we confirm that free flaps are extremely reliable in achieving successful reconstruction in the head and neck region. The recipient and donor site morbidity was limited and acceptable.

Careful pre-operative assessment, with particular attention paid to the anesthesiologist's status, history of surgery, and patient age, can help to identify patients who are at high risk to experience perioperative complications. When a compromised flap is identified, surgical reexploration should not be deferred.

\section{REFERENCES}

1. Brown JS, Devine JC, Magennis P, Sillifant P, Rogers SN, Vaughan ED. Factors that influence the outcome of salvage in free tissue transfer. $\mathrm{Br} \mathrm{J}$ Oral Maxillofac Surg 2003;41:16-20.

2. O'Brien CJ, Lee KK, Stern HS, Traynor SJ, Bron L, Tew PJ, et al. Evaluation of 250 free-flap reconstructions after resec-tion of tumours of the head and neck. Aust N Z J Surg 1998;68:698-701.

3. Singh B, Cordeiro PG, Santamaria E, Shaha AR, Pfister DG, Shah JP. Factors associated with complications in microvas-cular reconstruction of head and neck defects. Plast Reconstr Surg 1999; 103:403-11.

4. Shah JP, Haribhakti V, Loree TR, Sutaria P. Complications of the pectoralis major myocutaneous flap in head and neck reconstruction. Am J Surg 1990; 160:352-5

5. Schusterman M, Kroll S, Weber R, Byers R, Guillamondegui O, Goepfert H Intraoral soft tissue reconstruction after cancer ablation: A comparison of the pectoralis major flap and the free radial forearm flap. Am J Surg 1991:162:397-9.

6. Ferri T, Bacchi G, Bacciu A, Oretti G, Bottazzi D. The pecto-ralis major myocutaneous flap in head and neck reconstruc-tive surgery: 16 years of experience. Acta Biomed Ateneo Parmense 1999;70:13-7.

7. Bhaya MH. Har-el G. Resident training in head and neck flap reconstruction in US academic otolaryngology programmes. JLaryngol Otol 2001;115:119-21.

8. Genden EM, Rinaldo A, Suárez C, Wei WI, Bradley PJ, Ferlito A, et al. Complications of free flap transfers for head and neck reconstruction following cancer resection. Oral Oncol 2004:40:979-84.

9. Serletti JM, Higgins JP, Moran S, Orlando GS. Factors affect-ing outcome in free-tissue transfer in the elderly. Plast Reconstr Surg 2000; 106:66-70.

10. Farwell DG, Reilly DF, Weymuller EA Jr., Greenberg DL, Staiger TO, Futran NA. Predictors of perioperative compli-cations in head and neck patients. Arch Otolaryngol Head Neck Surg 2002;128:505-11.

11. Simpson KH, Murphy PG, Hopkins PM, Batchelor AG. Prediction of outcomes in 150 patients having microvascular free tissue transfers to the head and neck. Br J Plast Surg 1996;49:267-73.

12. Mücke T, Ritschl LM, Roth M, Güll FD, Rau A, Grill S, et al. Predictors of free flap loss in the head and neck region: A four-year retrospective study with 451 microvascu-lar transplants at a single centre J Craniomaxillofac Surg 2016:44:1292-8

13. Kim H, Jeong WJ, Ahn SH. Results of free flap reconstruction after ablative surgery in the head and neck. Clin Exp Otorhinolaryngol 2015;8:167-73.

14. Xu Z, Zhao XP, Yan TL, Wang M, Wang L, Wu HJ, et al. A 10-year retrospective study of free anterolateral thigh flap application in 872 head and neck tumour cases. Int J Oral Maxillofac Surg 2015:44:1088-94.

15. Bianchi B, Copelli C, Ferrari S, Ferri A, Sesenna E. Free flaps: Outcomes and complications in head and neck reconstructions. J Craniomaxillofac Surg 2009;37:438-42. 